\title{
ENDOGLYCOSIDASE H DIGESTION OF NEURONAL INTRACELLULAR LECTIN-BINDING SITES ${ }^{1}$
}

\author{
CLYDE E. HART AND JOHN G. WOOD ${ }^{2}$ \\ Department of Anatomy, Emory University School of Medicine, Atlanta, Georgia 30322 \\ Received November 3, 1983; Revised January 13, 1984; Accepted January 16, 1984
}

\begin{abstract}
Cerebellar Purkinje cells contain intracellular membrane systems that are highly enriched in concanavalin A (Con A)-binding sites and which may be involved in axonal and dendritic transport. We have attempted to characterize these Con A-binding sites in fixed slices of cerebellum by their susceptibility to endoglycosidase $\mathrm{H}$ (Endo $\mathrm{H}$ ) digestion. Tissue slices labeled with Con A-peroxidase without prior Endo $\mathrm{H}$ digestion had moderately dense label in the molecular and granular layers with the heaviest label occurring in Purkinje cell somata. Endo $\mathrm{H}$ digestion of tissue slices produced little change in the pattern of Con A label in the molecular and granular layers, but the Con A label in Purkinje ccll somata was removed except for small discrete patches. Electron microscopic examination of Purkinje cells from tissue slices not digested with Endo $\mathrm{H}$ showed Con A label in cisternal elements of the endoplasmic reticulum (ER), nuclear envelope, hypolemmal cisternae, and the Golgi complex. Presynaptic terminal smooth membrane cisternae and dendritic hypolemmal cisternae of Purkinje cells were also labeled with Con A-peroxidase. Endo H digestion removed Con A-binding sites in cisternae of the ER, somal and dendritic hypolemmal membrane system, and presynaptic terminal smooth membrane profiles. Con A-binding sites in the nuclear envelope and Golgi complexes of Purkinje cells were not removed by Endo $\mathrm{H}$ digestion. These results present ultrastructural evidence in support of biochemical studies which report the rough ER as the site of polymannose oligosaccharide addition to nascent polypeptides. The characterization of synaptic terminal smooth membrane and hypolemmal cisternae Con A-binding sites as polymannose or hybrid oligosaccharides may indicate that the complete maturation of glycoprotein carbohydrates to a complex type (Endo $\mathrm{H}$ resistant), found on the neuronal cell surface, occurs at or near the site of their insertion into the plasmalemma.
\end{abstract}

Membrane systems of cerebellar Purkinje cell neurons contain glycoconjugates that can be visualized by lectin cytochemical techniques (Wood et al., 1974, 1981; Wood and McLaughlin, 1976; Zanetta et al., 1978; IIatten et al., 1979). Cisternal elements of the rough endoplasmic reticulum (RFR), nuclear envelope, Golgi complex, presynaptic terminal smooth membrane profiles, and the endoplasmic reticulum (ER)-associated hypolemmal membrane system can be labeled with concanavalin A (Con A). The hypolemmal membrane system, a distinct subset of ER, lies subadjacent to the plasma membrane and extends from the cell soma through the dendritic tree and axon of the Purkinje cell (Kaiserman-Abramof and Palay, 1969; Palay and Chan-Palay, 1974).

\footnotetext{
${ }^{1}$ We wish to thank Dr. Joseph Besharse for useful comments and discussion concerning the manuscript. This work was supported by United States Public Health Science Grant NS-17731.

${ }^{2}$ To whom correspondence should be addressed.
}

The hypolemmal membrane system and presynaptic terminal smooth membrane profiles are possible morphological substrates for the fast transport of cell surface glycoproteins from the cell soma to the dendrites, axons, and presynaptic terminals (Kaiserman-Abramof and $\mathrm{Pa}$ lay, 1969; Palay and Chan-Palay, 1974; Wood et al., 1974, 1981; Wood and McLaughlin, 1976). In the cat cerebellum exogenous horseradish peroxidase (HRP) undergoing anterograde transport is associated with both smooth membrane cisternae lying directly beneath the axolemma and presynaptic smooth membrane profiles (Walberg et al., 1976). In the chick ciliary ganglion and preganglionic nerve, smooth membrane profiles in the region of the axolemma and in the presynaptic terminal have been implicated in the fast transport of radiolabeled glycoproteins (Bennett et al., 1973; DiGiamberardino et al., 1973; Droz et al., 1973). Since the hypolemmal cisternae and the presynaptic terminal smooth membrane profiles may participate in the fast transport of cell surface glycocon- 
jugates, characterization of their lectin-binding sites along with lectin-binding sites in other membrane compartments in the Purkine cell may provide more insight into the transport and processing of neuronal cell surface carbohydrates, as well as the transport of lectins introduced exogeneously into the cell (Stoeckel et al., 1977; Margolis et al., 1981; Ruda and Coulter, 1982; LaVail et al., 1983).

To characterize the Con A-binding sites in the Purkinje cell we have used a glycosidic enzyme, endo- $\beta-N$ acetylglucosaminidase $\mathrm{H}$ (Endo $\mathrm{H}$ ), to digest fixed cerebellar tissue slices prior to Con A-peroxidase labeling. The Endo $\mathrm{H}$ enzyme cleaves polymannose and smaller hybrid oligosaccharides in the chitobiose core of asparagine-linked glycoproteins. Our results indicate that the Con A-binding sites in the RER, hypolemmal membrane system, and presynaptic terminal smooth membrane profiles are polymannose and/or, hybrid-type asparaginelinked oligosaccharides of glycoproteins. A portion of this work has appeared in abstract form (Hart and Wood, 1983).

\section{Materials and Methods}

Concanavalin A (type IV), $\alpha$-methyl-D-mannoside, horseradish peroxidase (type VI), and $3-3^{\prime}$-diaminobenzidine were purchased from Sigma Chemical Co. (St. Louis, MO). Endo- $\beta$ - $N$-acetylglucosaminidase $\mathrm{H}(0.1$ unit vials) was from Miles Laboratories, Inc. (Elkhart, IN). Glutaraldehyde (8\%) and paraformaldehyde were from Polysciences, Inc. (Warrington, PA). All other chemicals were reagent grade.

Preparation of tissue. Male Sprague-Dawley rats (4 to 8 weeks old) were anesthetized by intraperitoneal injection of $35 \%$ chloral hydrate $(1 \mathrm{ml} / \mathrm{kg}$ of body weight) and were then perfused through the heart for $20 \mathrm{~min}$ with an ice-cold fixative containing $4.0 \%$ paraformaldehyde, $0.5 \%$ glutaraldehyde in $0.12 \mathrm{M}$ Millonig's buffer $(\mathrm{pH} 7.2)$ (Millonig, 1961). The cerebellum was removed and placed in $4 \%$ paraformaldehyde in $0.12 \mathrm{M}$ Millonig's buffer $(\mathrm{pH}$ 7.2 ) overnight at $4^{\circ} \mathrm{C}$. The next morning the cerebellum was cut parasagittally into $45-\mu \mathrm{m}$ slices with a Lancer Vibratome and collected in ice-cold PBS (pH 7.2); sections that were the most similar in overall morphology were chosen for further processing.

Enzyme incubations. Endo H (0.1 unit) was dissolved in $100 \mu \mathrm{l}$ of distilled water and diluted to $200 \mu \mathrm{l}$ with 100 $\mu \mathrm{l}$ of $0.30 \mathrm{M}$ citrate-phosphate buffer $(\mathrm{pH} 5.5)$. The final solution contained $0.05 \mathrm{~mm}$ phenylmethylsulfonyl fluoride (Sigma) as a protease inhibitor. One tissue slice per experiment was digested with the Endo $\mathrm{H}$ solution in a covered spot plate at $37^{\circ} \mathrm{C}$ with gentle agitation for 24 $\mathrm{hr}$. Tissue slices incubated in $200 \mu \mathrm{l}$ of $0.15 \mathrm{M}$ citratephosphate buffer minus Endo $\mathrm{H}$ were used for the enzyme control.

Lectin cytochemistry. All steps were performed with gentle agitation at room temperature except where indicated. After Endo H digestion, or an incubation in buffer without enzyme, the tissue slices were removed from the spot plate wells, washed for $10 \mathrm{~min}$ with citrate-phosphate buffer (two changes) followed by a PBS wash for 15 min (three changes). The tissue slices were incubated with Con A $(1 \mathrm{mg} / \mathrm{ml})$ in PBS for $30 \mathrm{~min}$ and were washed for $3 \mathrm{hr}$ in PBS (nine changes). A tissue slice in the citrate-phosphate buffer minus Endo $\mathrm{H}$ was incubated with Con A $(1 \mathrm{mg} / \mathrm{ml})$ in PBS containing $0.2 \mathrm{M} \alpha$ methyl-D-mannoside as a hapten control. Next, the slices were incubated in HRP $(0.1 \mathrm{mg} / \mathrm{ml})$ in PBS for $30 \mathrm{~min}$ and were then washed for $3 \mathrm{hr}$ in PBS (nine changes). The Con A-bound HRP was visualized by incubating the slices for $10 \mathrm{~min}$ in an ice-cold solution of 3-3'-diaminobenzidine (DAB) $(0.6 \mathrm{mg} / \mathrm{ml})$ in PBS containing $0.006 \% \mathrm{H}_{2} \mathrm{O}_{2}$. After the DAB incubation, the slices were washed for $30 \mathrm{~min}$ in PBS (three changes). Areas of the cerebellar cortex and dentate nucleus were cut from the slices and postfixed in $2 \% \mathrm{OsO}_{4}$ in $0.12 \mathrm{M}$ Millonig's buffer $(\mathrm{pH} \mathrm{7.2)}$ for $1 \mathrm{hr}$. These tissue pieces were stained en bloc with aqueous $1 \%$ uranyl acetate, dehydrated through an ethanol series and propylene oxide, and flat embedded in Embed 812-Araldite. Superficial ultrathin sections were taken parallel to the parasagittal tissue face and examined on a Phillips EM 400 electron microscope without staining the grids with either uranyl acetate or lead citrate. The remainder of each tissue slice was processed for light microscopy by a light osmication (4 drops of $4 \% \mathrm{OsO}_{4} / 100 \mathrm{ml}$ of PBS) for $15 \mathrm{sec}$ followed by dehydration through an ethanol series and xylene and was mounted on glass slides.

\section{Results}

\section{Light microscopy}

The Con A-labeling pattern of cerebellar tissue slices incubated in the citrate-phosphate buffer without Fndo $\mathrm{H}$ corresponds to the results of previous reports (Wood et al., 1974; Wood and McLaughlin, 1976) in which a $37^{\circ} \mathrm{C}$ incubation at pH 5.5 for $24 \mathrm{hr}$ was not done before cytochemical processing. This indicated that the long incubation period at $\mathrm{pH} 5.5$ did not rearrange or destroy the Con A-binding sites.

The buffer control tissue slices had a moderate amount of Con A label in the molecular and granular layers with the heaviest lahel located in the Purkinje cell somata (Fig. 1a). Tissue slices treated with Endo $\mathrm{H}$ prior to lectin cytochemistry still had a moderate amount of Con A label in the molecular and granular layers (Fig. 1b). The most striking effect of Endo $\mathrm{H}$ treatment was the almost complete removal of Con A label in the Purkinje cell somata (Fig. 1b). At a higher magnification the Purkinje cell somata of enzymc-treatcd tissuc werc virtually clear of Con A label except for small discrete patches and round vesicles (compare Fig. $1 c$ to $1 d$ ). The plasma membrane and the nuclear envelope area retained Con $\mathrm{A}$ label after Endo $\mathrm{H}$ digestion (Fig. $1 d$ and 3). Tissue slices incubated in the citrate-phosphate buffer minus Endo $\mathrm{H}$, followed by a Con A plus $0.2 \mathrm{M} \alpha$-methylD-mannoside incubation, were virtually free of label (inset, Fig. 1a).

\section{Electron microscopy}

Buffer control tissue slices labeled with Con A. Purkinje cell somata had Con A-peroxidase label located in cisternal elements of the Golgi complex, both smooth and 

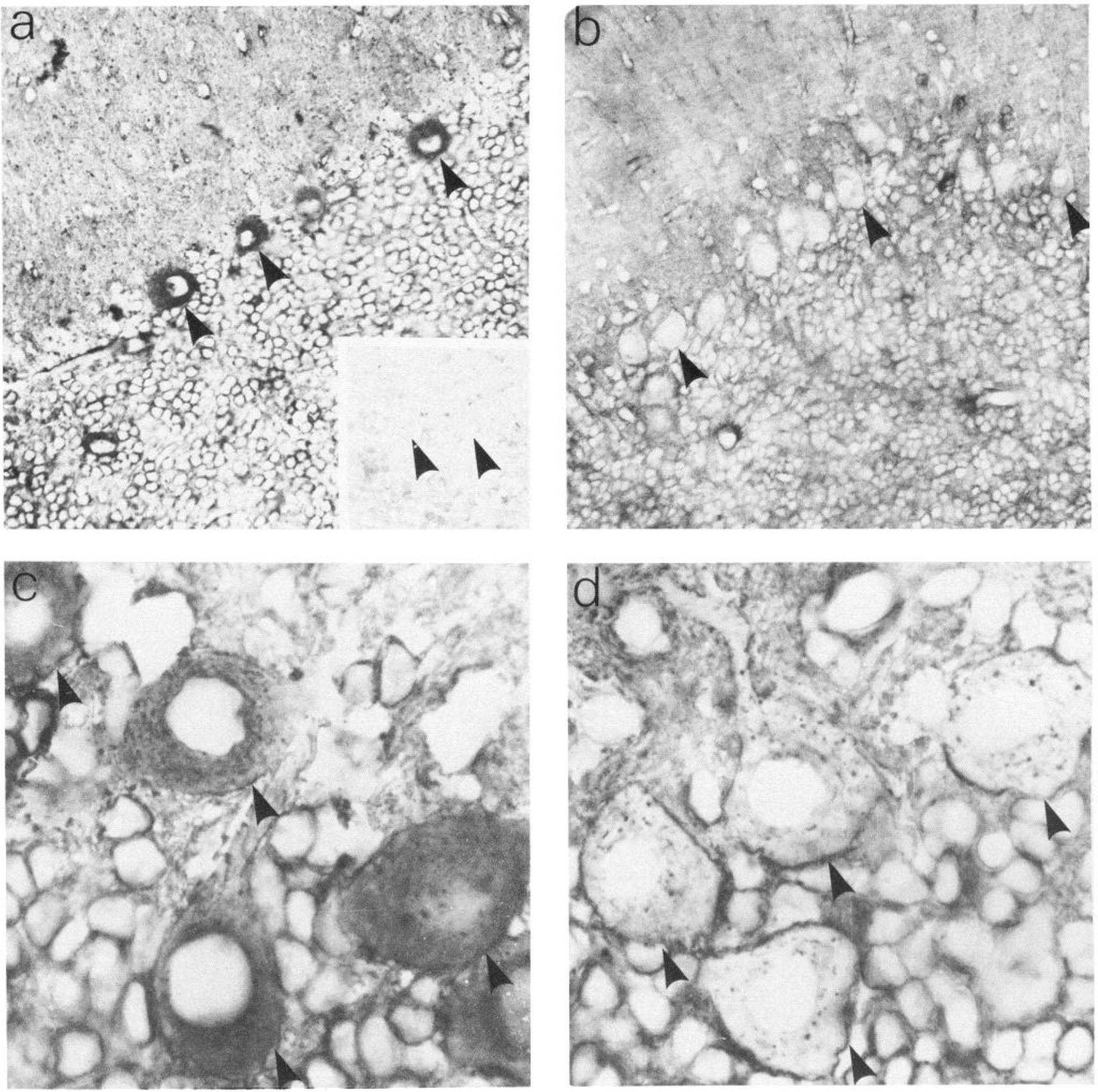

Figure 1. Cerebellar tissue slices labeled with Con A-peroxidase. $a$, Buffer-treated tissue slice with Con A label in the molecular layer (upper portion), granular layer (lower portion), and Purkinje cell somata (arrowheads). Inset, Tissue slice incubated in Con A plus hapten sugar. Magnification $\times 65 . b$, Endo H-treated tissue slice. Note the absence of label in the Purkinje cell somata (arrowheads). Magnification $\times 65$. c, Higher magnification showing Purkinje cell in buffer-treated tissue. Magnification $\times 255$. $d$, Higher magnification showing Purkinje cell in Endo H-treated tissue. Magnification $\times 255$.

rough ER including the nuclear envelope, and the hypolemmal cisternae (Fig. 2). The dendrites of Purkinje cells had Con A label restricted to the hypolemmal cisternae (Fig. 4c). Presynaptic terminals that fit the description of Purkinje cell terminals in the dentate nucleus (ChanPalay, 1977) had Con A label within smooth membrane cisternae (Fig. 4a). A majority of the labeled smooth membrane cisternae were found in the central portion of the terminal in close approximation to mitochondria
(Fig. 4a). This pattern of Con A labeling in Purkinje neurons after prolonged incubation at low $\mathrm{pH}$ is essentially the same as that seen in tissue processed immediately after Vibratome sectioning (Wood et al., 1974; Wood and McLaughlin, 1976).

Endo H-treated tissue slices labeled with Con A. Endo $\mathrm{H}$ digestion of the fixed cerebellar slices resulted in a selective loss of Con A-binding sites in the Purkinje cell somata. The conspicuous reduction of label in the cell 


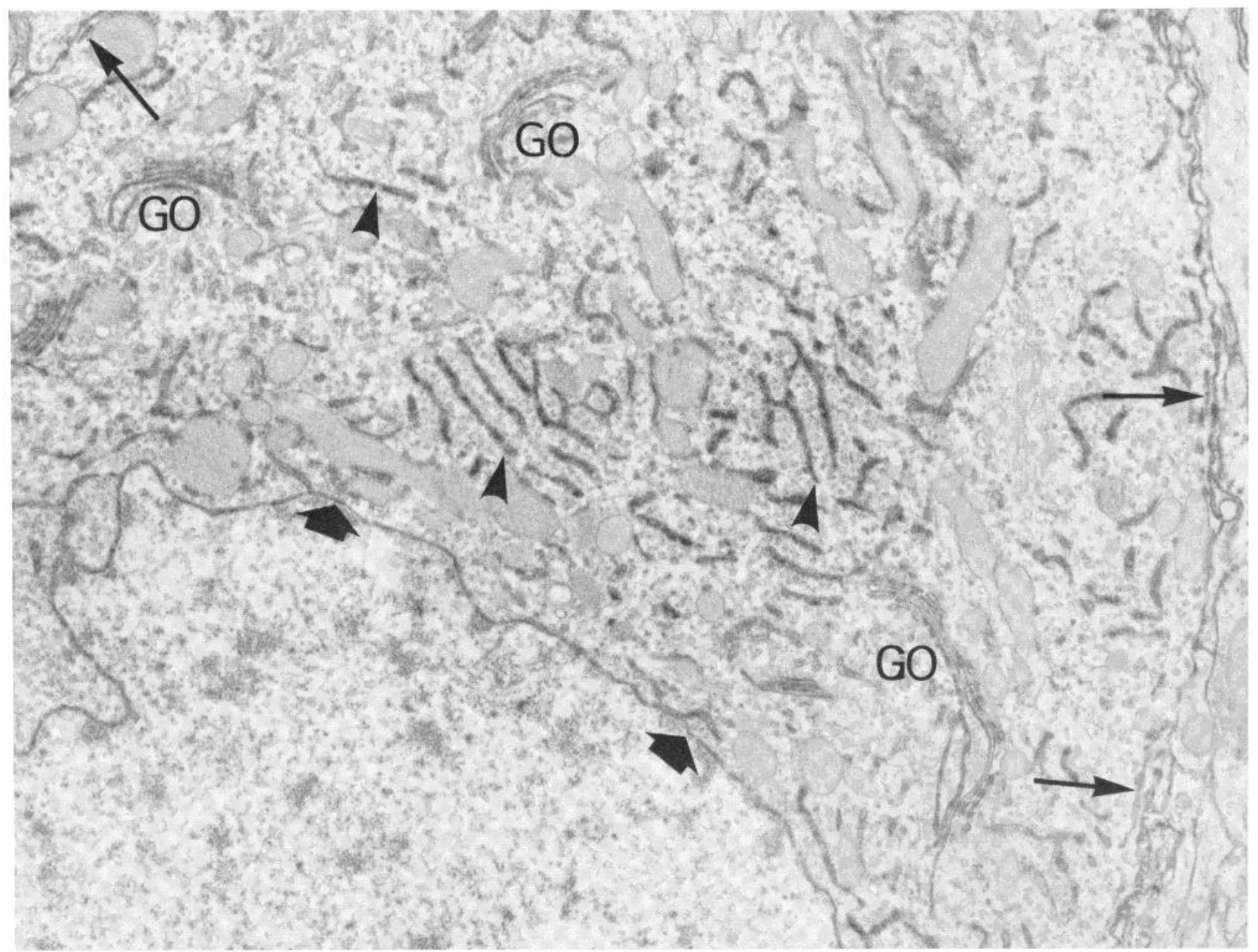

Figure 2. A portion of a Purkinje cell soma from a buffer-treated tissue slice labeled with Con A-peroxidase. The Con A label is present in cisternae of the nuclear envelope (block arrows), rough endoplasmic reticulum (arrowheads), Golgi complex (GO), and hypolemmal cisternae (arrows). Magnification $\times 16,100$.

somata observed at the light microscopic level resulted from the absence of Con A label in the cisternae of both smooth and rough ER (Fig. 3). Interestingly, Endo $\mathrm{H}$ treatment did not remove Con A label in the nuclear envelope. However, in another element of the ER, the hypolemmal cisternae, Con A-binding sites were removed by Endo $\mathrm{H}$ digestion (Fig. 3). A majority of the Golgi complexes in Purkinje cells of enzyme-treated tissue still had Con A label throughout cisternae of both the cis and trans saccules. In the hypolemmal cisternae of Purkinje cell dendrites, Con A label was drastically reduced or abolished in Endo H-treated tissue (Fig. 4, $d$ and $e$ ). This observation was consistent throughout the numerous Purkinje cell dendritic profiles examined by electron microscopy. Examination of dendrites from a buffer control tissue slice versus a dendrite from an Endo H-treated tissue slice illustrates the loss or salient reduction of Con A receptors in the hypolemmal cisternae of enzymetreated tissue (compare Fig. $4 c$ and $4 d$ ). In presynaptic terminals of Purkinje cells the Con A-binding sites in smooth membrane cisternae were removed by Endo $\mathrm{H}$ treatment (Fig. $4 b$ ). Observations of numerous thin sec- tions from enzyme-treated tissue slices showed the mitochondria-associated smooth membrane cisternae in the central portion of the synaptic terminal to be free of Con A label (Fig. $4 b$ ). Con A label was found infrequently in the cisternae of larger membrane-bound vesicles in the peripheral portion of the synaptic terminal (not shown). When this type of labeled vesicle was followed in serial sections, it was seen to be an infolding of the presynaptic plasma membrane.

\section{Discussion}

Endo $\mathrm{H}$, the endoglycosidase enzyme first described and later reviewed by Maley and co-workers (Tarentino and Maley, 1974; Tarentino et al., 1978), has been an important tool in the analysis of glycoprotein structure and synthesis. Endo $\mathrm{H}$ cleaves polymannose and smaller hybrid-type oligosaccharides of asparagine-linked glycoproteins between the two $N$-acetylglucosamine (GlcNAc) residues in the chitobiose core. Larger hybridtype and complex-type oligosaccharides are resistant to hydrolysis by Endo H (Tarentino et al., 1978). Also, the 


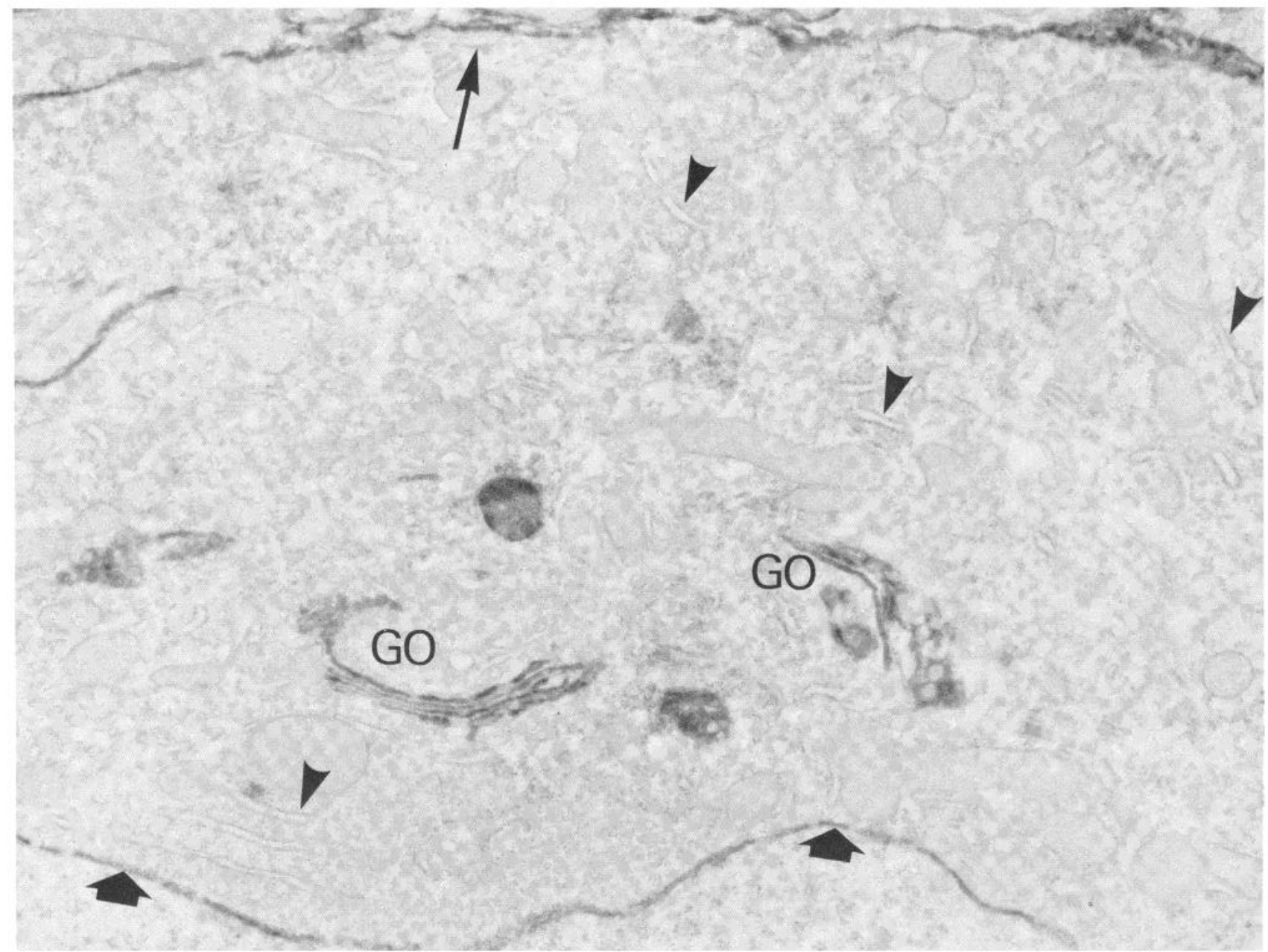

Figure 3. A portion of a Purkinje cell soma from a tissue slice treated with Endo $\mathrm{H}$ prior to Con A-peroxidase cytochemistry. Endo $\mathrm{H}$ treatment removes Con A-binding sites in cisternae of the rough endoplasmic reticulum (arrowheads) and hypolemmal cisternae (long arrow). Con A label remains in cisternae of the Golgi complex $(G O)$ and nuclear envelope (block arrows). Magnification $\times 21,000$.

attachment of fucose to the inner GlcNAc in the chitobiose core abolishes the enzymatic action of Endo $\mathrm{H}$ (Tarentino and Maley, 1975; Tarentino et al., 1978).

In our experiments, Endo $\mathrm{H}$ digestion of tissue slices prior to lectin cytochemistry removed Con A-binding sites in the cisternae of the RER. The specificity of Endo $\mathrm{H}$ enzymatic action and previous biosynthetic studies described below indicate that these lectin receptors are polymannose or, less likely, a hybrid type.

Biosynthetic studies with ${ }^{3} \mathrm{H}$-amino acids incorporated into glycoproteins in either cell-free translation systems or pulse-chase experiments in cell culture have reported the initial glycosylation event in the RER as an en bloc transfer of a polymannose oligosaccharide to a polypeptide still bound to the ribosome (for a review, see Hubbard and Ivatt, 1981). Several lines of evidence indicate that the transfer of the lipid-bound oligosaccharide to an acceptor polypeptide occurs within the cisternae of the RER. The majority of this evidence comes from the observations that protein-linked carbohydrates are found primarily on the cisternal side of RER membrane preparations (Rothman and Lenard, 1977; Rodriguez-Boulan et al., 1978; Hanover and Lennarz, 1980) and in cell-free translation systems, protein glycosylation occurs only when microsomal membranes are included (Rothman and Lodish, 1977; Garoff et al., 1978; Linagappa et al., 1978; Toneguzzo and Ghosh, 1978; Bielinska et al., 1979; Dobberstein et al., 1979; Korman et al., 1980).

Pulse-chase experiments with cultured cells infected with vesicular stomatis virus (VSV) show that during the pulse and for a brief chase period the newly synthesized VSV glycoprotein is susceptible to endoglycosidase attack (Robbins et al., 1977; Tabas et al., 1978; Schmidt and Schlesinger, 1980). Taken together our lectin cytochemical results and the biochemical results described above support the opinion that the initial glycosylation of asparagine-linked glycoproteins occurs in the cisternae of the RER and that the added oligosaccharide is a polymannose type. The presence of Con A receptors in cisternae of the nuclear envelope of Purkinje cells after Endo $\mathrm{H}$ digestion suggests that this portion of RER may contain complex or larger hybrid-type oligosaccharides. Lectin cytochemical experiments with cryostat sections of adult mouse cerebellum by Hatten et al. (1979) found 

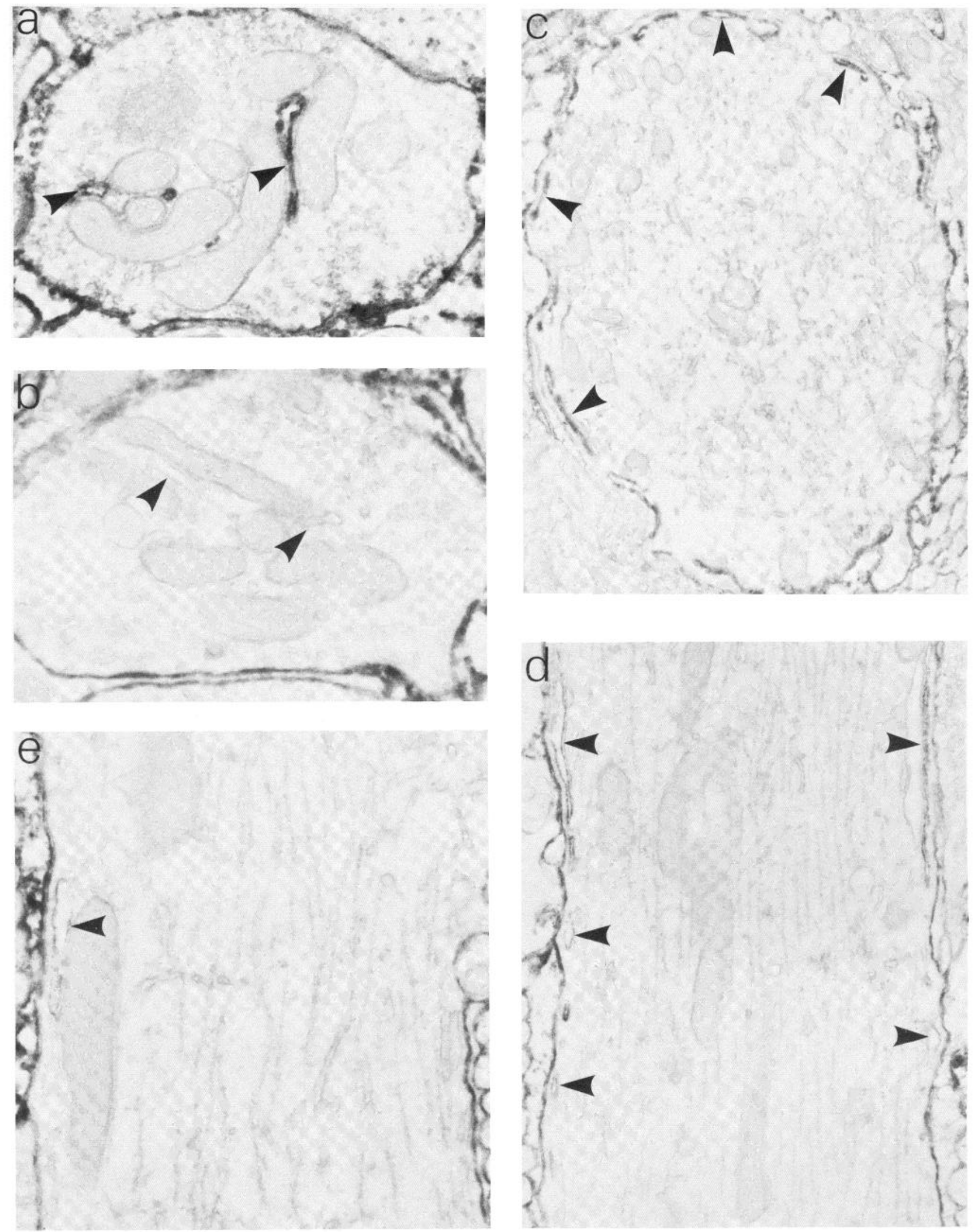

Figure 4. a, Purkinje cell presynaptic terminal in the dentate nucleus from a buffer-treated tissue slice. Smooth membrane cisternae (arrowheads) have Con A label. Magnification $\times 37,500 . b$, Purkinje cell terminal in the dentate nucleus from a tissue slice treated with Endo H. Note the absence of Con A label in smooth membrane cisternae (arrowheads). Magnification $\times 46,200$. $c$, Purkinje cell dendrite from a buffer-treated tissue slice. The Con A label is present in the hypolemmal cisternae (arrowheads). Magnification $\times 21,060 . d$ and $e$, Purkinje cell dendrites from Endo H-treated tissue slices. Con A-binding sites are removed or greatly reduced in the hypolemmal cisternae (arrowheads). Magnifications: $d, \times 25,740 ; e, \times 32,760$. 
wheat germ agglutinin (WGA) to label the nuclear envelope area but not the somata of Purkinje cells. The differences in lectin labeling and Endo $\mathrm{H}$ susceptibility of carbohydrates in the nuclear envelope compared to the RER suggests a possible functional heterogeneity between these two RER compartments that is yet to be determined.

Endo $\mathrm{H}$ digestion did not reduce Con $\mathrm{A}$ label in the Golgi cisternae. This was not an unexpected result since glycosidase and glycosyltransferase activity reported to occur in the Golgi complex (for a review, see Rothman, 1981) would modify the polymannose oligosaccharides and make them Endo $\mathrm{H}$ resistant. Glycosyltransferase activities for the transfer of $N$-acetylglucosamine (GlcNAc), galactose (Gal), and $N$-acetylneuraminic acid (NANA) to protein-bound oligosaccharides have been localized in trans-Golgi subcellular fractions (Bretz et al., 1980) and galactosyltransferase activity in the transGolgi by immunohistochemistry (Roth and Berger, 1982), so a fraction of the total Con A-binding sites in the cis-Golgi should be Endo $\mathrm{H}$ susceptible. However, the removal of mannosyl residues by $\alpha$-mannosidases reported to be in the cis-Golgi (Kornfeld et al., 1978; Dunphy et al., 1981; Dunphy and Rothman, 1983) produces a three mannose-core oligosaccharide which is hydrolyzed by Endo $\mathrm{H}$ at a rate approximately $1 / 10,000$ that of larger polymannose and small hybrid-type oligosaccharides (Tarentino et al., 1978). Therefore, a group of Con A receptors in the cis-Golgi resistant to Endo H would possibly remain after the enzyme treatment. Also the possible addition of a fucosyl sugar to the chitobiose core would render the oligosaccharide Endo $\mathrm{H}$ resistant (Tarentino and Maley, 1975; Tarentino et al., 1978).

In tissue slices treated with Endo $\mathrm{H}$, the removal or drastic reduction of Con A-binding sites in the hypolemmal cisternae of both the somata and dendrites of Purkinje cells suggests that many of the oligosaccharides lining this membrane system are polymannose or small hybrid types. This observation is interesting in light of the hypolemmal membrane system possibly serving as a fast transport system for cell surface macromolecules in the axons and dendrites of Purkinje cells (KaisermanAbramof and Palay, 1969; Palay and Chan-Palay, 1974; Wood et al., 1974, 1981; Wood and McLaughlin, 1976; Walberg et al., 1976). The association of fast transported proteins with a sublemmal domain in dendrites of spinal cord motor neurons has been demonstrated in autoradiographic studies (Schubert and Kreutzberg, 1975). A sublemmal association of fast transported proteins in dendrites (Schubert and Kreutzberg, 1975) and a similar sublemmal position of the lectin-labeled hypolemmal cisternae (Wood et al., 1974; Wood and McLaughlin, 1976) conveys a possible parallel between the fast transport process and the hypolemmal cisternae. It is, of course, not possible at this time to rule out the possibility that the hypolemmal cisternae are not in a precursorproduct relationship with the plasmalemma. However, the absence of WGA-binding sites (NANA or GlcNAc residues) in the hypolemmal cisternae (Wood et al., 1981) suggests that if the hypolemmal cisternae is a membrane system used for fast transport of cell surface glycoproteins, the addition of terminal sugars which are characteristic of complex glycoproteins on the cell surface might occur at sites on or near their point of insertion into the plasma membrane (Wood et al., 1981). This is supported by the observation that WGA receptors on neuronal plasma membranes are removed by neuraminidase treatment, but WGA labeling in the Golgi cisternae remains after neuraminidase treatment (Wood et al., 1981). Since all glycoproteins destined for the cell surface are thought to pass through and are modified in the Golgi apparatus (Palade, 1975; Rothman, 1981; Hammerschlag and Stonc, 1982), the obscrvation that WGA labcling in the Golgi complex is not removed or decreased after neuraminidase treatment suggests that the addition of terminal NANA residues to oligosaccharides might occur on post-Golgi membranes. It should be noted that the absence of WGA staining in the hypolemmal cisternae cannot be taken as conclusive evidence that a population of NANA containing glycoconjugates does not exist there since it is possible that unknown factors may influence the binding of WGA to this system.

The removal of Con A-binding sites in smooth membrane cisternae of presynaptic terminals by Endo $\mathrm{H}$ digestion suggests that the majority of these carbohydrates are polymannose or hybrid type. As in the dendritic hypolemmal cisternae, the possibility of polymannose or hybrid-type oligosaccharides being fast transported to the presynaptic terminal and there being modified to a complex-type oligosaccharide may exist. Biochemical studies using subcellular fractionation of nervous tissue have described glycosyltransferase activity in synaptosomal fractions (Dutton et al., 1973; Den et al., 1975; Goodrum et al., 1979; Preti et al., 1980; Rostas et al., 1981). The relatively high amounts of unsubstituted $\mathrm{Gal}$ and GlcNAc sugars on the nonreducing end of asparagine-linked oligosaccharides in calf brain microsomes (Krusius and Finne, 1977) and the observation that $\left[{ }^{3} \mathrm{H}\right]-N$-acetylgalactosamine injected directly into the L2 axon of Aplysia is incorporated into glycoproteins undergoing fast axonal transport (Ambron and 'Treistman, 1977) support the concept of oligosaccharide modification in post-Golgi compartments. The localization of anterogradely transported HRP in smooth membrane profiles of Purkinje cell presynaptic terminals (Walberg et al., 1976) gives credence for the involvement of this membrane compartment in glycoprotein transport.

These experiments have demonstrated the ability to characterize, at the ultrastructural level, carbohydrates lining the cisternae of various membrane compartments in the Purkinje neuron. Endo $\mathrm{H}$ hydrolysis of Con Abinding sites in the RER cisternae supports the concept of polymannose oligosaccharides being transfered to nascent polypeptides at this subcellular location. The inability of the enzyme to remove Con A receptors in the Golgi complex corroborates localization of $\alpha$-mannosidase activity in the cis-Golgi and terminal glycosyltransferase enzymes in the trans-Golgi. Characterization of Con A-binding sites in the dendritic hypolemmal cister nae and presynaptic terminal smooth membrane cisternae as polymannose or hybrid-type oligosaccharides suggests that if these membrane-bound compartments participate in the transport of cell surface glycoproteins, the addition of terminal sugars characteristic of the neuronal plasma membrane (especially NANA) might occur at a site close to or on the cell surface. 


\section{References}

Ambron, R. T., and S. N. Treistman (1977) Glycoproteins are modified in the axon of $\mathrm{R} 2$, the giant neuron of Aplysia californica, after intra-axonal injection of $\left[{ }^{3} \mathrm{H}\right] \mathrm{N}$-acetylgalactosamine. Brain Res. 121: 287-309.

Bennett, G., L. DiGiamberardino, H. L. Koenig, and B. Droz (1973) Axonal migration of protein and glycoprotein to nerve endings. II. Radioautographic analysis of the renewal of glycoproteins in nerve endings of chicken ciliary ganglion after intracerebral injection of $\left[{ }^{3} \mathrm{H}\right]$ fucose and $\left[{ }^{3} \mathrm{H}\right]$ glucosamine. Brain Res. 60: 129-146.

Bielinska, M., G. Rogers, T. Rucinsky, and I. Boime (1979) Processing in vitro of placental peptide hormones by smooth microsomes. Proc. Natl. Acad. Sci. U. S. A. 76: 6152-6156.

Bretz, R., H. Bretz, and G. E. Palade (1980) Distribution of terminal glycosyltransferases in hepatic Golgi fractions. J. Cell Biol. 84: 87-101.

Chan-Palay, V. (1977) Cerebellar Dentate Nucleus, pp. 257259, Springer-Verlag, New York.

Den, H., B. Kaufman, E. J. McGuire, and S. Roseman (1975) The sialic acids. XVIII. Subcellular distribution of seven glycosyltransferases in embryonic chicken brain. J. Biol. Chem. 250: 739-746.

DiGiamberardino, L., G. Bennett, H. Koenig, and B. Droz (1973) Axonal migration of protein and glycoprotein to nerve endings. III. Cell fraction analysis of chicken ciliary ganglion after intracerebral injection of labeled precursors of protein and glycoproteins. Brain Res. 60: 147-159.

Dobberstein, B., H. Garoff, G. Warren, and P. J. Robinson (1979) Cell-free synthesis and membrane insertion of mouse $\mathrm{H}-2 \mathrm{D}^{\mathrm{d}}$ histocompatibility antigen and $\mathrm{B}_{2}$-microglobulin. Cell 17: $759-769$.

Droz, B., H. Koenig, and L. DiGiamberardino (1973) Axonal migration of protein and glycoprotein to nerve endings. I. Radioautographic analysis of the renewal of protein in nerve endings of chicken ciliary ganglion after intracerebral injection of $\left[{ }^{3} \mathrm{H}\right]$ lysine. Brain Res. $60: 93-127$.

Dunphy, W. G., and J. E. Rothman (1983) Compartmentation of asparagine-linked oligosaccharide processing in the Golgi apparatus. J. Cell Biol. 97: 270-275.

Dunphy, W. G., E. Fries, L. J. Urbani, and J. E. Rothman (1981) Early and late functions associated with the Golgi apparatus reside in distinct compartments. Proc. Natl. Acad. Sci. U. S. A. 78: 7453-7457.

Dutton, G. R., P. Haywood, and S. H. Barondes (1973) $\left[{ }^{14} \mathrm{C}\right]$ Glucosamine incorporation into specific products in the nerve ending fraction in vivo and in vitro. Brain Res. 57: $397-408$.

Garoff, H., K. Simons, and B. Dobberstein (1978) Assembly of the Semliki Forest virus membrane glycoproteins in the membrane of the endoplasmic reticulum in vitro. J. Mol. Biol. 124: 587-600.

Goodrum, J. F., H. B. Bosmann, and R. Tanaka (1979) Glycoprotein galactosyltransferase activity in synaptic junctional complexes isolated from rat forebrain. Neurochem. Res. 4: 331-337.

Hammerschlag, R., and G. C. Stone (1982) Membrane delivery by fast axonal transport. Trends Neurosci. 5: 12-15.

Hanover, J. A., and W. J. Lennarz (1980) $N$-linked glycoprotein assembly: Evidence that oligosaccharide attachment occurs within the lumen of the endoplasmic reticulum. J. Biol. Chem. 255: 3600-3604.

Hart, C. E., and J. G. Wood (1983) The effects of endoglycosi dase digestion of lectin binding sites in the rat cerebellum. Anat. Rec. 205: 75A-76A.

Hatten, M. E., M. Schachner, and R. L. Sidman (1979) Histochemical characterization of lectin binding in mouse cerebellum. Neuroscience 4: 921-935.
Hubbard, S. C., and R. J. Ivatt (1981) Synthesis and processing of asparagine-linked oligosaccharides. Annu. Rev. Biochem. 50: $555-583$.

Kaiserman-Abramof, I. R., and S. L. Palay (1969) Fine structural studies of the cerebellar cortex in a mormyrid fish. In Neurobiology of Cerebellar Evolution and Development, R. Llinas, ed. pp. 171-205, AMA-ERF Institute for Biomedical Research, Chicago.

Korman, A. J., H. L. Ploegh, J. F. Kaufman, M. J. Owen, and J. L. Strominger (1980) Cell-free synthesis and processing of the heavy and light chains of HLA-DR antigens. J. Exp. Med. 152: $65 \mathrm{~S}-82 \mathrm{~S}$.

Kornfeld, S., E. Li, and I. Tabas (1978) The synthesis of complex-type oligosaccharides. II. Characterization of the processing intermediates in the synthesis of the complex oligosaccharide units of the vesicular stomatitis virus $G$ protein. J. Biol. Chem. 253: 7771-7778.

Krusius, T., and J. Finne (1977) Structural features of tissue glycoproteins: Fractionation and methylation analysis of glycopeptides derived from rat brain, kidney, and liver. Eur. J. Biochem. 78: 369-379.

LaVail, J. H., I. K. Sugino, and D. M. McDonald (1983) Localization of axonally transported ${ }^{125}$ I-wheat germ agglutinin beneath the plasma membrane of chick retinal ganglion cells. J. Cell Biol. 96: 373-381.

Linagappa, V. R., J. R. Lingappa, R. Prasad, K. E. Ebner, and G. Blobel (1978) Coupled cell-free synthesis, segregation, and core glycosylation of a secretory protein. Proc. Natl. Acad. Sci. U. S. A. 75: 2338-2342.

Margolis, T. P., C. M. F. Marchand, H. G. Kistler, and J. H. LaVail (1981) Uptake and anterograde axonal transport of wheat germ agglutinin from retina to optic tectum in the chick. J. Cell Biol. 89: 152-156.

Millonig, G. (1961) Advantages of a phosphate buffer for $\mathrm{OsO}_{4}$ solutions in fixation. J. Appl. Physiol. 32: 1637.

Palade, G. (1975) Intracellular aspects of the process of protein synthesis. Science 189:347-358.

Palay, S. L., and V. Chan-Palay (1974) Cerebellar Cortex, pp. 28-29, Springer-Verlag, New York.

Preti, A., A. Fiorilli, A. Lombardo, L. Caimi, and G. Tettamanti (1980) Occurrence of sialyltransferase activity in synaptosomal membranes prepared from calf brain cortex. J. Neurochem. 35: 281-296.

Robbins, P. W., S. C. Hubbard, S. J. Turco, and D. F. Wirth (1977) Proposal for a common oligosaccharide intermediate in the synthesis of membrane glycoproteins. Cell 12: 893900.

Rodriguez-Boulan, E., G. Kreibich, and D. D. Sabatini (1978) Spatial orientation of glycoproteins in membranes of rat liver rough microsomes. I. Localization of lectin-binding sites in microsomal membranes. J. Cell Biol. 78: 874-893.

Rostas, J. A. P., W. N. Leung, and P. L. Jeffrey (1981) Glycosyltransferase activities in chicken brain synaptic junctions. Neurosci. Lett. 24: 155-160.

Roth, J., and E. G. Berger (1982) Immunocytochemical localization of galactosyltransferase in HeLa cells: Codistribution with thiamine pyrophosphatase in trans-Golgi cisternae. J. Cell Biol. 93: 223-229.

Rothman, J. E. (1981) The Golgi apparatus: Two organelles in tandem. Science 213: 1212-1219.

Rothman, J. E., and J. Lenard (1977) Membrane asymmetry. Science 195: 743-753.

Rothman, J. E., and H. F. Lodish (1977) Synchronized transmembrane insertion and glycosylation of a nascent membrane protein. Nature 269: 775-780.

Ruda, M., and J. D. Coulter (1982) Axonal and transneuronal transport of wheat germ agglutinin demonstrated by immunocytochemistry. Brain Res. 249: 237-246.

Schmidt, M. F. G., and M. J. Schlesinger (1980) Relation of 
fatty acid attachment to the translation and maturation of vesicular stomatitis virus and Sindbis virus membrane glycoproteins. J. Biol. Chem. 255: 3334-3339.

Schubert, P., and G. W. Kreutzberg (1975) Parameters of dendritic transport. Adv. Neurol. 12: 255-268.

Stoeckel, K., M. Schwab, and H. Thoenen (1977) Role of gangliosides in the uptake and retrograde axonal transport of cholera and tetanus toxin as compared to nerve growth factor and wheat germ agglutinin. Brain Res. 132: 273-285.

Tabas, I., S. Schlesinger, and S. Kornfeld (1978) Processing of high mannose oligosaccharides to form complex type oligosaccharides on the newly synthesized polypeptides of vesicular stomatitis virus $\mathrm{G}$ protein and the IgG heavy chain. J. Biol. Chem. 253: 716-722.

Tarentino, A. L., and F. Maley (1974) Purification and properties of an endo- $\beta-N$-acetylglucosaminidase from Streptomyces griseus. J. Biol. Chem. 249: 811-817.

Tarentino, A. L., and F. Maley (1975) A comparison of the substrate specificities of endo- $\beta-N$-acetylglucosaminidases from Streptomyces griseus and Diplococcus pneumoniae. Biochem. Biophys. Res. Commun. 67: 455-462.

Tarentino, A. L., R. B. Trimble, and F. Maley (1978) Endo- $\beta$ $N$-acetylglucosaminidase from Streptomyces plicatus. In Methods Enzymol. 50: 574-580.

Toneguzzo, F., and H. P. Ghosh (1978) In vitro synthesis of vesicular stomatitis virus membrane glycoprotein and insertion into membranes. Proc. Natl. Acad. Sci. U. S. A. 75: 715719.

Walberg, F., A. Brodal, and G. H. Hoddevik (1976) A note on the method of retrograde transport of horseradish peroxidase as a tool in studies of afferent cerebellar connections, particularly those from the inferior olive; with comments on the orthograde transport in Purkinje cell axons. Exp. Brain Res. 24: $383-401$.

Wood, J. G., and B. J. McLaughlin (1976) Cytochemical studies of lectin binding sites in smooth membrane cisternac of rat brain. Brain Res. 118: 15-26.

Wood, J. G., B. J. McLaughlin, and R. P. Barber (1974) The visualization of concanavalin A binding sites in Purkinje cell somata and dendrites of rat cerebellum. J. Cell Biol. 63: 541549.

Wood, J. G., F. I. Byrd, and J. W. Gurd (1981) Lectin cytochemistry of carbohydrates on cell membranes of rat cerebellum. J. Neurocytol. 10: 149-159.

Zanetta, J. P., G. Roussel, M. S. Ghandour, G. Vincendon, and G. Gombos (1978) Postnatal development of rat cerebellum: A massive and transient accumulation of concanavalin A binding glycoproteins in parallel fiber axolemma. Brain Res. 142: 301-319. 